\title{
Expression of the Streptomyces aureofaciens glyceraldehyde-3-phosphate dehydrogenase gene (gap) is developmentally regulated and induced by glucose
}

\author{
J. Kormanec, A. Lempel'ová, R. Nováková, B. Řežuchová \\ and D. Homérová
}

\begin{abstract}
Author for correspondence: J. Kormanec. Tel: +4217378 2432. Fax: +4217372316. e-mail: umbijkor@savba.sk
\end{abstract}

Institute of Molecular Biology, Slovak Academy of Sciences, 84251

Bratislava, Slovak Republic

\begin{abstract}
In previous experiments, the Streptomyces aureofaciens gap gene encoding glyceraldehyde-3-phosphate dehydrogenase (GAPDH) was identified. To investigate expression of the gene, $\mathrm{S1}$ nuclease mapping and Northern blot hybridization were performed using RNA prepared from S. aureofaciens cultivated under various conditions. These studies suggested monocistronic organization and developmental regulation of the gene. A single promoter, gap-P, was identified upstream of the gap coding region. In cultures grown on solid medium in the absence of glucose, its transcription was induced at the time of aerial mycelium formation. In addition, gap transcription was also induced in substrate mycelium by glucose. A promoter-bearing DNA fragment was inserted into two promoter-probe vectors, to give expression patterns consistent with the results of direct RNA analysis.
\end{abstract}

Keywords: Streptomyces aureofaciens, differentiation, transcription, promoter, glyceraldehyde-3-phosphate dehydrogenase

\section{INTRODUCTION}

Most work on mycelial Gram-positive Streptomyces species has been concerned with molecular studies on the genes for secondary metabolism. Molecular studies of primary metabolism have received comparatively little attention in these organisms. Studies with several examples of primary metabolic genes have indicated different regulatory mechanisms from those of Escherichia coli (Angell et al., 1992; Smith \& Chater, 1988).

Recently, we have identified and partially characterized a gene, gap, encoding glyceraldehyde-3-phosphate dehydrogenase (GAPDH) in Streptomyces aureofaciens (Kormanec et al., 1995). GAPDH, a key enzyme of glycolysis, reversibly catalyses the oxidative phosphorylation of glyceraldehyde 3-phosphate to 1,3-bisphosphoglycerate using $\mathrm{NAD}^{+}$as coenzyme (Harris \& Waters, 1976). GAPDH-encoding genes have been identified in various bacteria and transcriptional studies have been reported. In Zymomonas mobilis, cultivated in the

Abbreviations: GAPDH, glyceraldehyde-3-phosphate dehydrogenase: tsp, transcription start point.

The GenBank/EMBLDDBJ accession number for the sequence reported in this paper is U21191. presence of glucose, at least two tandem promoters were identified upstream of the gap gene, but other carbon sources were not investigated (Conway et al., 1987). Based on the GAPDH activities in the presence and absence of glucose, constitutive expression of the gap gene has been suggested in Corynebacterium glutamicum (Eikmanns, 1992). The only detailed study of transcriptional regulation has been done in E. coli by Charpentier \& Branlant (1994). Their analysis of gapA transcription revealed a complex regulation comprising four tandemly organized promoters recognized by two different RNA polymerase holoenzymes.

To elucidate a possible function for the gap gene in $S$. aureofaciens, we have analysed its expression under various conditions, including different stages of development and the presence of different carbon sources. The data obtained show temporally different expression of the gap gene during $S$. aureofaciens differentiation and induction of expression by glucose.

\section{METHODS}

Bacterial strains, plasmids and culture conditions. S. aureofaciens CCM3239 wild-type (ATCC 10762) was from the Czechoslovak Collection of Micro-organisms, Brno, Czech Republic. S. lividans TK24 (Hopwood et al., 1985) was a kind 


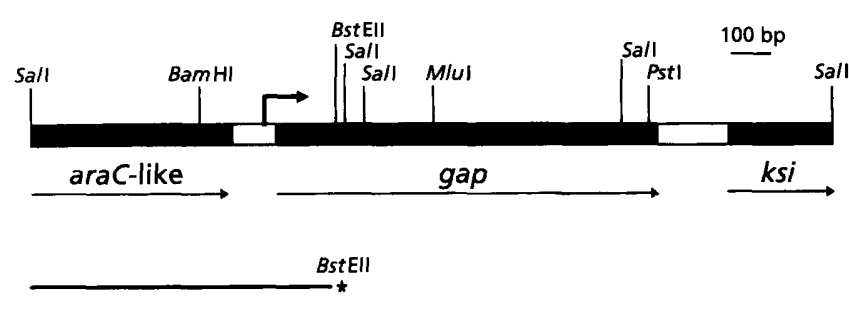

BamHI Pst

Fig. 1. Restriction map of the gap gene and strategy for transcript mapping. Filled boxes indicate ORFs. The angled arrow represents the apparent direction of transcription from the gap-P promoter. The line below the map represents a DNA fragment ( $5^{\prime}$-labelled at the end marked with an asterisk) that was used as probe in $\$ 1$ nuclease mapping. The black bar below the maps represents the probe used for Northern hybridization analysis. Relevant restriction sites used in S1 mapping and cloning are indicated.

gift from D. A. Hopwood, John Innes Institute, Norwich, UK. Plasmid pARC1 (Horinouchi \& Beppu, 1985) was a kind gift from S. Horinouchi, University of Tokyo, and pIJ4083 (Clayton \& Bibb, 1990) from Mervyn Bibb, John Innes Institute, Norwich, UK. E. coli SURE (Stratagene) was used as host and plasmid pBluescriptII SK + (Stratagene) was used for $E$. coli cloning experiments. Growth, transformation of $S$. lividans and plasmid isolation were carried out as described in Hopwood et al. (1985). Thiostrepton was used for selection of pIJ4083- and pARC1-based plasmids at a final concentration of $10 \mu \mathrm{g} \mathrm{ml}^{-1}$, low enough to avoid inhibition of development but high enough to maintain selection. For RNA isolation, $S$. aureofaciens was cultured to late exponential phase $(20 \mathrm{~h})$ in liquid NMP medium (Hopwood et al., 1985) containing different carbon sources at $1 \%$ final concentration. For RNA isolation from surface culture, $10^{8}$ spores of $S$. aureofaciens wild-type strain were spread on sterile cellophane membranes placed on Bennet medium (Horinouchi et al., 1983) and grown for $13 \mathrm{~h}$ (substrate mycelium), $19 \mathrm{~h}$ (beginning of aerial mycelium) and $36 \mathrm{~h}$ (late aerial mycelium stage). Conditions for $E$. coli growth and transformation were as described in Ausubel et al. (1987).

DNA manipulations. DNA manipulations in $E$. coli were done as described in Ausubel et al. (1987) and those in Streptomyces were as described by Hopwood et al. (1985). DNA fragments were isolated from agarose gel using GeneClean (Bio101). Nucleotide sequencing was performed by the chemical method (Maxam \& Gilbert, 1980).

RNA isolation. Total RNA was prepared from surface cultures of $S$. aureofaciens as described previously (Kormanec \& Farkašovský, 1994). The integrity of RNA was indicated by sharp rRNA bands after electrophoresis in agarose containing $2 \cdot 2 \mathrm{M}$ formaldehyde (Ausubel et al., 1987) and staining with ethidium bromide.

S1 nuclease mapping. High-resolution S1 nuclease mapping was performed as described previously (Kormanec \& Farkašovský, 1993). Samples $(40 \mu \mathrm{g})$ of RNA (estimated spectrophotometrically using a Beckman DU-20 spectrophotometer) were hybridized to approximately $0.1 \mathrm{pmol}$ suitable DNA probe labelled at one $5^{\prime}$ end with $\left[\gamma^{32} \mathrm{P}\right]$ ATP [approx. $10^{6}$ c.p.m. (pmol probe) ${ }^{-1}$ ]. The probe used (Fig. 1) was an 800 bp SalI-BstEII fragment uniquely labelled at the $5^{\prime}$ end at the BstEII site. The $b r d B-\mathrm{P} 2$ promoter probe has been described by Kormanec \& Farkašovský (1993). The protected DNA fragments were analysed on DNA sequencing gels together with $\mathrm{G}+\mathrm{A}$ and $\mathrm{T}+\mathrm{C}$ sequencing ladders derived from the end-labelled fragments (Maxam \& Gilbert, 1980). Before assigning the transcription start point (tsp), $1.5 \mathrm{nt}$ was subtracted from the length of the protected fragment to account for the difference in the $3^{\prime}$ ends resulting from S1 nuclease digestion and the chemical sequencing reactions.

Northern blot hybridization. Samples of RNA $(10 \mu \mathrm{g})$ were dissolved in formamide and separated on $1.2 \%(\mathrm{w} / \mathrm{v})$ agarose gels in the presence of $2.2 \mathrm{M}$ formaldehyde as described in Ausubel et al. (1987). After electrophoresis, RNA was blotted onto a Hybond-N membrane (Amersham) and hybridized at $44{ }^{\circ} \mathrm{C}$ for $16 \mathrm{~h}$ in hybridization solution $[50 \%(\mathrm{v} / \mathrm{v})$ formamide, $5 \times \mathrm{SSPE}\left(1 \times \mathrm{SSPE}\right.$ is $0 \cdot 18 \mathrm{M} \mathrm{NaCl} / 10 \mathrm{mM} \mathrm{NaH}_{2} \mathrm{PO}_{4} /$ 1 mM EDTA, pH 7.4), $5 \times$ Denhardt's solution ( $1 \times$ Denhardt's solution is $0.02 \%$ Ficoll $/ 0.02 \% \mathrm{BSA} / 0.02 \%$ polyvinylpyrrolidone), $0.5 \%$ SDS, $20 \mu \mathrm{g}$ fresh denatured sonicated herring sperm DNA $\mathrm{ml}^{-1}$ ] with a random-primed-labelled (Boehringer) $1170 \mathrm{bp} \mathrm{BamHI-PstI} \mathrm{DNA} \mathrm{fragment} \mathrm{(Fig.} \mathrm{1).} \mathrm{After}$ hybridization, the filter was washed successively for $15 \mathrm{~min}$ at room temperature in $2 \times \mathrm{SSC} / 0.1 \% \mathrm{SDS}, 0.5 \times \mathrm{SSC} / 0.1 \%$ SDS, $0 \cdot 1 \times \mathrm{SSC} / 0.1 \% \mathrm{SDS}$, and twice for $30 \mathrm{~min}$ at $65^{\circ} \mathrm{C}$ in $0 \cdot 1 \times$ SSC $/ 0 \cdot 1 \%$ SDS and autoradiographed $(1 \times$ SSC is $0.3 \mathrm{M}$ $\mathrm{NaCl} / 0.03 \mathrm{M}$ sodium citrate, $\mathrm{pH} 7$ ).

Detection of promoter activity in vivo. The activity of promoters cloned in promoter-probe plasmid pIJ4083 was detected on plates using the $x y l E$ reporter gene. Plates containing patches of $S$. lividans TK24 carrying plasmid pXYL-GAP1 or pIJ4083 at various developmental stages were sprayed with an aqueous solution of $0.5 \mathrm{M}$ catechol. A yellow colour, associated with production of 2-hydroxymuconic semialdehyde, was visible after about $10 \mathrm{~min}$. For quantitative assays, $10^{8}$ spores of $S$. lividans containing the corresponding plasmid were spread on sterile cellophane membranes placed on MM or Bennet medium (with $1 \%$ carbon source and $10 \mu \mathrm{g}$ thiostrepton $\mathrm{ml}^{-1}$ ) and grown for 24, 30, 50, 70, 120 and $170 \mathrm{~h}$. Samples were collected in duplicate and cell extracts were prepared as described in Homerová et al. (1996). The activity of catechol 2,3-dioxygenase activity was determined as described by Ingram et al. (1989). The protein concentration was determined by the method of Bradford (1976). Activity of promoters after cloning in promoter-probe plasmid pARC1 was detected during differentiation of $S$. lividans TK24 grown on Bennet medium with $10 \mu \mathrm{g}$ thiostrepton $\mathrm{ml}^{-1}$ and different carbon sources ( $1 \%$ final concentration) as described by Horinouchi \& Beppu (1985).

\section{RESULTS}

\section{The $5^{\prime}$ upstream region of the gap gene has promoter activity}

Upstream of the $S$. aureofaciens gap gene there is a $185 \mathrm{bp}$ intergenic region that suggests the presence of a promoter directing gap expression (Kormanec et al., 1995). To prove this, the $800 \mathrm{bp} \mathrm{SalI-BstEII} \mathrm{fragment}$ containing this region (Fig. 1) was cloned in high-copynumber promoter-probe plasmid pIJ4083 (Clayton \& Bibb, 1990). Since this plasmid is unable to replicate in $S$. aureofaciens (Kormanec et al., 1993), the corresponding recombinant $\mathrm{pXYL-GAP1}$ was used to transform the heterologous host S. lividans TK24. The activity of catechol 2,3-dioxygenase encoded by the $x y l E$ reporter gene was checked during differentiation of colonies on 


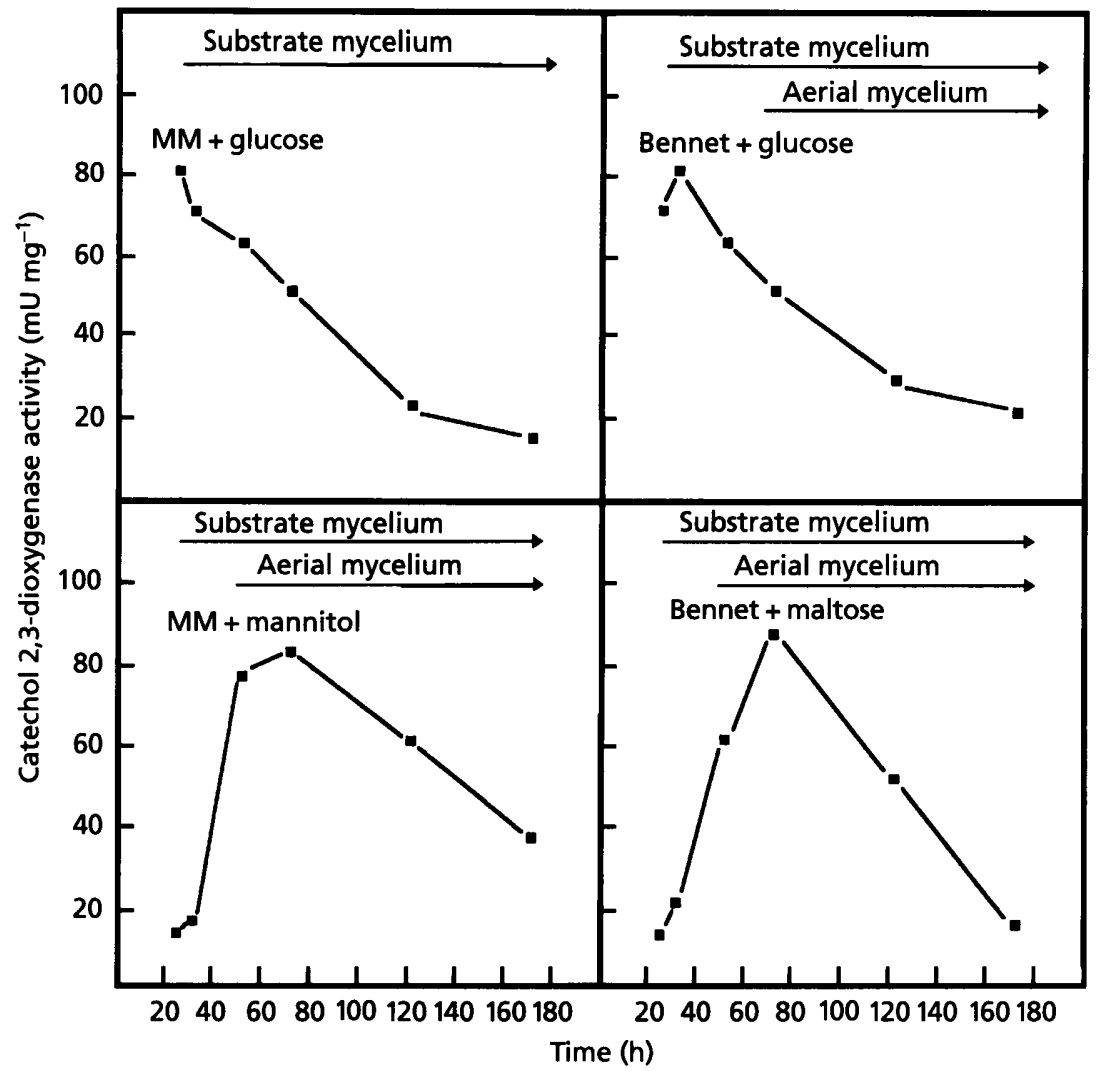

Fig. 2. Time course of catechol 2,3dioxygenase activity in S. lividans containing pXYL-GAP1 grown on solid medium. Spores $\left(10^{8}\right)$ were spread on sterile cellophane membranes placed on MM or Bennet medium (with $1 \%$ carbon source and $10 \mu \mathrm{g}$ thiostrepton $\mathrm{ml}^{-1}$ ) and grown for 24, 30, 50, 70,120 and $170 \mathrm{~h}$. Cell extracts were obtained and activity measured as described in Methods. The mean specific activity of catechol 2,3-dioxygenase in $S$. lividans containing plJ4083 was $2 \mathrm{mU}^{-1}$. This value was subtracted from the results. The graphs represent mean data from duplicate sets of samples isolated from the same plates. solid medium growing on different carbon sources (glucose, maltose, galactose and mannitol) by spraying the plates with a $0.5 \mathrm{M}$ solution of catechol. This colourless compound is converted by catechol 2,3dioxygenase to the intensely yellow 2-hydroxymuconic semialdehyde (Ingram et al., 1989). Two types of media were used; minimal medium MM (Hopwood et al., 1985) and rich Bennet medium (Horinouchi et al., 1983). Results indicated clear promoter activity of the cloned fragment that was both carbon-source-dependent and developmentally regulated. For all carbon sources other than glucose, yellow colour (indicating promoter activity) was detected only at the time of aerial mycelium formation. When grown in the presence of glucose, the promoter was active from the beginning of growth. As a negative control, S. lividans/pIJ4083 (on the same plate) was white after spraying with catechol during all stages of differentiation. To quantitatively estimate induction of $x y l E$ reporter expression by glucose, the specific activity of catechol 2,3-dioxygenase was determined in a cell extract of $S$. lividans containing pXYL-GAP1 or pIJ4083 grown on solid medium with several representative carbon sources for $24,30,50,70,120$ and $170 \mathrm{~h}$ (Fig. 2). The results suggested that the putative gap promoter was induced by glucose in substrate mycelium, and in the absence of glucose the promoter was induced at the time of aerial mycelium formation. In all cases, the activity of the promoter decreased in the late stages of differentiation.

To investigate whether the high copy number of the pIJ4083-based plasmid influenced the induction of gap-
$\mathrm{P}$ promoter, the same promoter-bearing fragment as above was cloned in low-copy-number promoter-probe plasmid pARC1 (Horinouchi \& Beppu, 1985), resulting in plasmid pARC-GAP1. Strong production of brown marker pigment occurred in substrate mycelium of $S$. lividans containing pARC-GAP1 grown on solid Bennet medium in the presence of glucose. When maltose, mannitol or galactose were used as carbon source, the marker brown pigment was almost invisible in substrate mycelium. However, the expression of the pigment dramatically increased at the time of aerial mycelium formation and remained until the late developmental stages. The results were thus similar to the $x y l E$ reporter system. Together, these results suggest a rather complicated regulation of the gap gene in which expression is regulated in two different ways. In substrate mycelium, gap expression is induced by glucose; during differentiation, the expression is induced by an unknown signal at the time of aerial mycelium formation.

\section{The gap gene is transcribed from a single promoter}

Since in previous experiments heterologous strain $S$. lividans was used to detect promoter activity, highresolution S1 nuclease mapping was used to confirm these results using the RNA from $S$. aureofaciens. RNA was extracted from $S$. aureofaciens grown in liquid NMP medium in the presence of different carbon sources (glucose, mannitol and maltose), and from $S$. aureofaciens grown on solid Bennet medium with maltose during differentiation. This is the best medium for 


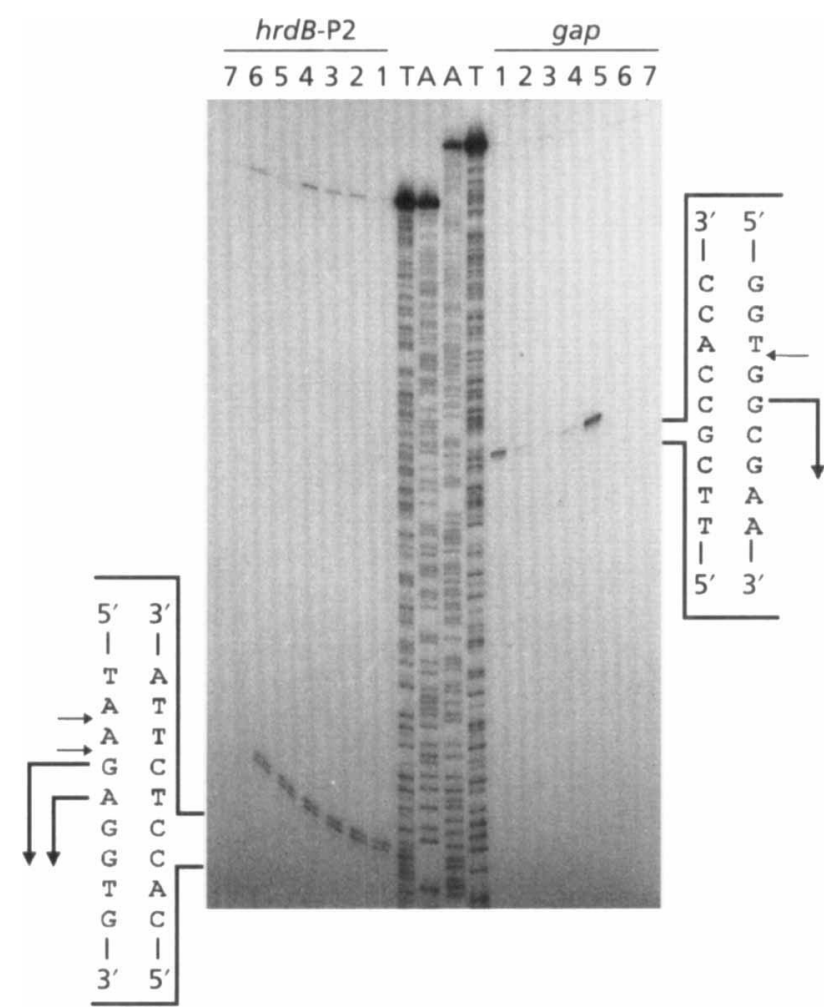

Fig. 3. High-resolution $S 1$ nuclease mapping of apparent tsps for the $S$. aureofaciens gap gene. A 5 '-labelled DNA fragment (Fig. 1) was hybridized with $40 \mu \mathrm{g}$ RNA and treated with $100 \mathrm{U}$ S1 nuclease as described in Methods. Lanes on right: 1, RNA from $S$. aureofaciens grown in minimal liquid NMP medium with glucose to the end of exponential phase (20 h); 2, RNA from $S$. aureofaciens grown in minimal liquid NMP medium with mannitol to the end of exponential phase $(20 \mathrm{~h}) ; 3$, RNA from $S$. aureofaciens grown in minimal liquid NMP medium with maltose to the end of exponential phase $(20 \mathrm{~h}) ; 4$, RNA from $S$. aureofaciens grown on solid Bennet medium with maltose for $13 \mathrm{~h}$ (substrate mycelium); 5, RNA from $S$. aureofaciens grown on solid Bennet medium with maltose for $19 \mathrm{~h}$ (beginning of aerial mycelium formation); 6 , RNA from $S$. aureofaciens grown on solid Bennet medium with maltose for $36 \mathrm{~h}$ (aerial mycelium approximately $5 \mathrm{~h}$ before pigment production characteristic of sporulation); $7, E$. coli tRNA as control. A control S1 nuclease mapping experiment with the same RNA samples was done using a DNA probe for the $h r d B$ P2 promoter (lanes on left). Thin horizontal arrows indicate the position of RNA-protected fragments and bold angled arrows indicate the nucleotides corresponding to apparent tsps after subtraction of $1.5 \mathrm{nt}$. Tracks $A$ and $T$ are $G+A$ and $T+C$ sequencing ladder fragments, respectively (Maxam \& Gilbert, 1980). All of the $S 1$ nuclease mapping experiments were performed three times with independent sets of RNA samples. In every experiment, the same RNA preparations were hybridized in parallel with all of the probes.

sporulation of $S$. aureofaciens. Surface-grown cells of $S$. aureofaciens were harvested 13,19 and $36 \mathrm{~h}$ after inoculation of spores. These times correspond to the substrate mycelium growth (13 h), as well as early (19 h) and late $(36 \mathrm{~h})$ aerial mycelium formation. RNA was hybridized to the $5^{\prime}$-labelled probe indicated in Fig. 1. After S1 treatment, a single RNA-protected fragment was identified (Fig. 3). The fragment corresponded to an

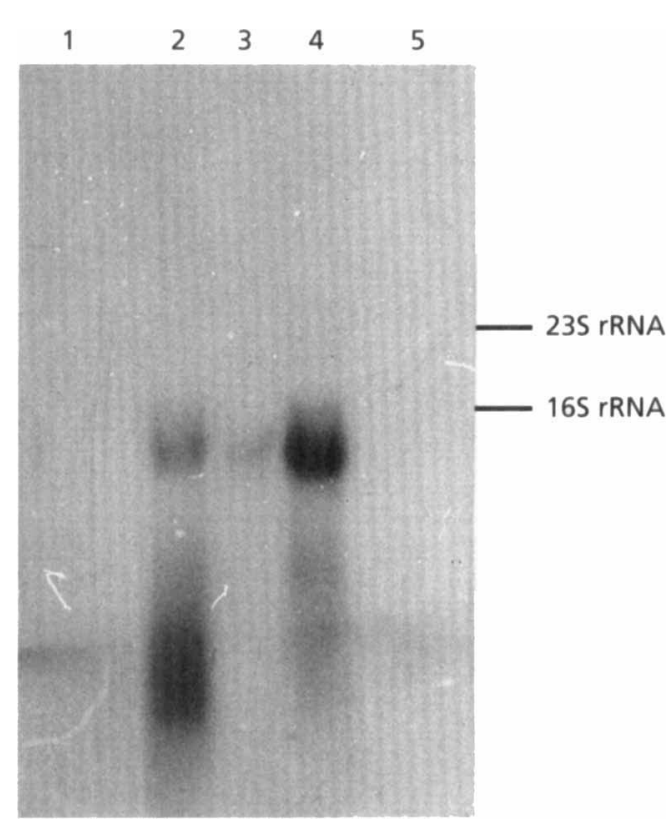

Fig. 4. Northern blot hybridization analysis of the gap transcript. Total RNA $(10 \mu \mathrm{g})$ was separated on a $1.2 \%$ agarose gel in the presence of $2.2 \mathrm{M}$ formaldehyde, blotted to Hybond$\mathrm{N}$ membrane (Amersham) and hybridized with random-primedlabelled DNA probe (Fig. 1) as described in Methods. Lanes: 1, RNA from $S$. aureofaciens grown in minimal liquid NMP medium with mannitol to the end of exponential phase $(20 \mathrm{~h})$; 2 , RNA from $S$. aureofaciens grown in minimal liquid NMP medium with glucose to the end of exponential phase $(20 \mathrm{~h}) ; 3$, RNA from $S$. aureofaciens grown on solid Bennet medium with maltose for $13 \mathrm{~h}$ (substrate mycelium); 4, RNA from $\mathrm{S}$. aureofaciens grown on solid Bennet medium with maltose for $19 \mathrm{~h}$ (beginning of aerial mycelium formation); 5, RNA from $\mathrm{S}$. aureofaciens grown on solid Bennet medium with maltose for $36 \mathrm{~h}$ (aerial mycelium approximately $5 \mathrm{~h}$ before pigment production characteristic of sporulation). Positions of the internal rRNAs shown. The size of the gap transcript was calculated using the rRNAs as internal standards, assuming that their sizes are as in $S$. ambofaciens: 235 rRNA $=3120 \mathrm{nt}$; $16 S$ rRNA $=1528$ nt (Pernodet et al., 1989).

apparent promoter termed gap-P with a tsp at a $G$ residue 23 bp upstream from the most likely translation initiation codon (see Fig. 5). Substantially more RNAprotected fragment was identified with RNA isolated from $S$. aureofaciens grown in liquid minimal medium glucose-NMP (Fig. 3, lane 1), compared to cultures grown in mannitol- or maltose-NMP (Fig. 3, lanes 2 and 3). The same RNA-protected fragment was identified using RNA prepared from surface-grown $S$. aureofaciens. The intensity of the RNA-protected fragment was much higher using RNA prepared from the beginning of aerial mycelium formation (Fig. 3, lane 5) than with RNA isolated from substrate mycelium (Fig. 3 , lane 4). The intensity of the protected fragment decreased substantially using RNA from a late stage of differentiation (Fig. 3, lane 6). A very weak fragment was visible only after long overexposure of the autoradiogram (data not shown). No RNA-protected fragment was identified with tRNA as a control (Fig. 3, lane 7). 
ORF1 (AraC-like)

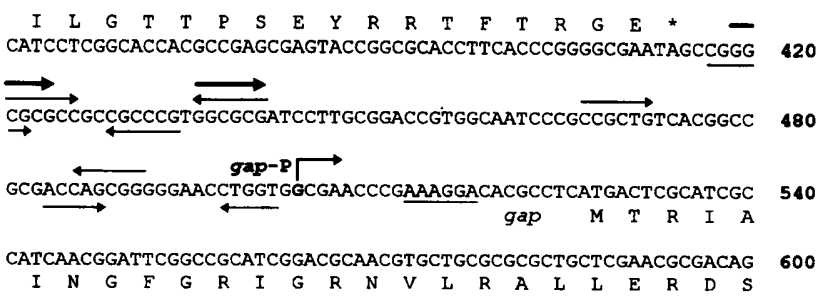

$\begin{array}{lllllllllllllllllllll}I & N & G & F & G & R & I & G & R & N & V & \text { L } & R & A & \text { L } & \text { L } & \text { E } & R & \text { D } & S\end{array}$

Fig. 5. The nucleotide sequence of the $S$. aureofaciens gap-P promoter region. The angled arrow indicates the likely position of the tsp and the direction of transcription. The $G$ residue of the tsp is bold. A presumptive RBS is underlined. The one-letter arnino acid code is used under the second position of each codon. A stop codon is marked by an asterisk. Inverted repeats are designated by thin arrows. A tandem repeat is designated by bold arrows. The numbers correspond to the nucleotide positions in the published sequence of the gene (Kormanec et al., 1995).

As a comparative control for normalization, S1 mapping was performed with the same RNA samples using a probe fragment specific for $S$. aureofaciens brdB-P2 promoter, which is expressed fairly constantly during differentiation (Kormanec \& Farkašovský, 1993). As shown in Fig. 3, protected fragments of similar intensities corresponding to the $h r d B-P 2$ promoter were identified with all RNA samples.

\section{The gap transcript is monocistronic}

Results of previous studies (Kormanec et al., 1995) suggested that the identified gap gene was not organized in a multicistronic operon. To verify this, Northern blot hybridization was performed with RNA isolated from $S$. aureofaciens cultured under similar conditions as for $\mathrm{S} 1$ mapping experiments, using a DNA fragment comprising the whole gap gene as a probe (Fig. 1). The results revealed a unique signal of about $1060 \mathrm{nt}$ (Fig. 4). This length closely corresponded to the predicted size of gap transcript (about $1070 \mathrm{nt}$ ), supposing that transcription was initiated at the gap-P promoter and terminated at the inverted repeat downstream of the gap gene (Kormanec et al., 1995). The gap transcript was induced by glucose in substrate mycelium (Fig. 4, lane 2) and at the time of aerial mycelium formation using RNA isolated from $S$. aureofaciens grown on solid medium (Fig. 4, lane 4), similar to the results of S1 mapping. The results of Northern blot hybridization proved the proposed monocistronic organization of gap in $S$. aureofaciens.

\section{Characterization of the gap-P promoter}

The sequence of the gap-P promoter and flanking regions is shown in Fig. 5. An inspection of the DNA sequence upstream of the apparent tsp of the gap-P promoter revealed several inverted and direct repeats that might be implicated in regulation of its activity. The

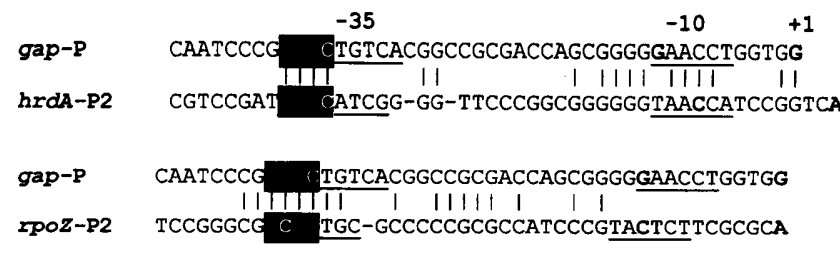

Fig. 6. Comparison of the putative $S$. aureofaciens gap-P promoter with promoters having the greatest similarity in the -10 and -35 regions; hrdA-P2 directs expression of the putative $\sigma$ factor gene $h r d A$ in $S$. aureofaciens (Kormanec \& FarkaŠovský, 1993) and rpoZ-P2 directs the expression of the putative $\sigma$ factor gene $r p o Z$, crucial in initiating sporulation in S. aureofaciens (Kormanec et al., 1996). Apparent tsps, -10 and -35 positions are in bold. The putative -10 and -35 regions are underlined. The conserved CCGC region is highlighted in black.

putative -10 (GAACCT) and -35 (CTGTCA) regions of the gap-P promoter (Fig. 6) show limited similarity to the -10 (TAgPuPuT) and -35 (TTGACPu) consensus sequences for $\mathrm{E} \sigma^{70}$-like promoters (Strohl, 1992).

Comparison of the putative gap-P promoter with 139 compiled promoter regions from Streptomyces spp. (Strohl, 1992) revealed some similarity to two $S$. aureofaciens promoters: $h r d A-\mathrm{P} 2$ (mostly around the -10 region) and $r$ poZ-P2 (highest similarity around the -35 region) (Fig. 6). The $h r d A-P 2$ promoter directs expression of a putative $\sigma$ factor gene ( $h r d A)$ homologous to the principal $\sigma$ factor in $S$. aureofaciens (Kormanec \& Farkašovský, 1993), and the rpoZ-P2 promoter is upstream of the putative $\sigma$ factor gene that is crucial in initiating sporulation in S. aureofaciens $(r p o Z)$ (Kormanec et al., 1994, 1996). It is interesting that, similar to gap-P, activity of both promoters is induced at the beginning of aerial mycelium formation (Kormanec \& Farkašovský, 1993; Kormanec et al., 1996). Thus, all these promoters might be regulated by a common mechanism at the beginning of sporulation. It is worth mentioning that the conserved region CCGC is present in all of these promoters around the -35 region (Fig. 6).

\section{DISCUSSION}

Our data reported here demonstrate a different regulation of gap expression compared to other bacteria. Based on in vitro transcription studies, the $S$. aureofaciens gap gene is transcribed as a monocistronic mRNA from a single promoter. Interestingly, its transcription is strongly induced by the presence of glucose in the culture medium. To our knowledge, this is the first report of induction of bacterial glycolytic genes by glucose. In the filamentous fungus Aspergillus oryzae, transcription of another glycolytic gene, encoding enolase, is also induced in the presence of glucose (Machida et al., 1996).

When gap expression was investigated in the absence of 
glucose during differentiation on solid medium, strong induction of the same promoter was identified at the time of aerial mycelium formation. This dual type of regulation of a single promoter was surprising. Whereas Streptomyces genes are regulated by tandem promoters that are differentially activated, in S. aureofaciens, gap is under the control of a single promoter with a dual regulatory role. In the presence of glucose, substrate mycelium expression is induced by glucose, but in its absence, expression is induced by a signal(s) at the time of aerial mycelium formation. In this respect, it is interesting that the gap-P promoter is most similar to two $S$. aureofaciens promoters, $h r d A-\mathrm{P} 2$ and rpoZ-P2, which are similarly induced at the time of aerial mycelium formation. Glucose induction of the S. aureofaciens gap gene is intriguing since most hexose sugars are catabolized by the glycolytic pathway and catabolism of each sugar requires GAPDH. This may be the role of the second gap gene suggested in $S$. aureofaciens (Kormanec et al., 1995). The cloning of this gene is in progress. On the other hand, the induction at the time of aerial mycelium formation in the absence of glucose might be connected with phase I glycogen degradation that occurs during Streptomyces differentiation in substrate hyphae that undergo aerial mycelium formation (Homerová et al., 1996; Plaskitt \& Chater, 1995). Based on this assumption, the expression of gap might be induced not only by external glucose, but also by some glucose metabolite that is generated after phase I glycogen degradation at the beginning of aerial mycelium formation. Based on the S1 mapping data, the expression of the gap gene substantially decreased later in sporulation when secondary (phase II) accumulation and degradation of glycogen occurs. This might be a possible role of the proposed second gap gene also in glycogen consumption.

A putative gene homologous to transcriptional activators of the AraC family has been identified upstream of the S. aureofaciens gap gene (Kormanec et al., 1995). Usually transcriptional activators of this family are located upstream of the gene (operon) they regulate (Gallegos et al., 1993). Thus, it is possible that glucose induction of the S. aureofaciens gap gene is mediated by a protein encoded by this gene. Experiments to determine this are in progress. However, some preliminary experiments have already indicated the binding of this protein on the DNA fragment containing the promoter region of gap (J. Kormanec, unpublished results). The results from transcriptional fusions of gap in S. lividans show similar temporal expression as shown by $\mathrm{S} 1$ mapping data in $S$. aureofaciens. This suggests that $S$. lividans might contain a gap gene under similar regulation to the gap gene in $S$. aureofaciens, or is able to supply this putative activator in trans.

\section{ACKNOWLEDGEMENTS}

We would like to thank Mrs Renáta Knirschová for excellent technical assistance. We are grateful to Professor David A. Hopwood for providing us with S. lividans TK24, Mervyn J.
Bibb for plasmid pIJ4083 and S. Horinouchi for plasmid pARC1. This work was supported by Grant 2/4007/97 from the Slovak Academy of Sciences.

\section{REFERENCES}

Angell, S., Schwarz, E. \& Bibb, M. (1992). The glucose kinase gene of Streptomyces coelicolor A3(2): its nucleotide sequence, transcriptional analysis and role in glucose repression. Mol Microbiol 6, 2833-2844.

Ausubel, F. M., Brent, R., Kingston, R. E., Moore, D. O., Seidman, J. S., Smith, J. A. \& Struhl, K. (1987). Current Protocols in Molecular Biology. New York: Wiley.

Bradford, M. M. (1976). A rapid and sensitive method for the quantitation of microgram quantities of protein utilizing the principle of protein-dye binding. Anal Biochem 72, 248-254.

Charpentier, B. \& Branlant, C. (1994). The Escherichia coli gapA gene is transcribed by the vegetative RNA polymerase holoenzyme $\mathrm{E} \sigma^{70}$ and by the heat shock RNA polymerase $\mathrm{E} \sigma^{32}$. $J$ Bacteriol 176, 830-839.

Clayton, T. M. \& Bibb, M. J. (1990). Streptomyces promoter-probe plasmids that utilise the $x y l E$ gene of Pseudomonas putida. Nucleic Acids Res 18, 1077.

Conway, T., Sewell, G. W. \& Ingram, L. O. (1987). Glyceraldehyde3-phosphate dehydrogenase gene from Zymomonas mobilis: cloning, sequencing, and identification of promoter region. J Bacteriol 169, 5653-5662.

Eikmanns, B. J. (1992). Identification, sequence analysis, and expression of a Corynebacterium glutamicum gene cluster encoding the three glycolytic enzymes, glyceraldehyde 3-phosphate dehydrogenase, 3-phosphoglycerate kinase, and triosephosphate isomerase. J Bacteriol 174, 6076-6086.

Gallegos, M. T., Michan, C. \& Ramos, J. L. (1993). The XylS/AraC family of regulators. Nucleic Acids Res 21, 807-810.

Harris, J. I. \& Waters, M. (1976). Glyceraldehyde-3-phosphate dehydrogenase. In The Enzymes, Vol. XIII, pp. 1-49. Edited by P. D. Boyer. New York: Academic Press.

Homerová, D., Benada, O., Kofroňová, O., Řežuchová, B. \& Kormanec, J. (1996). Disruption of a glycogen branching enzyme gene, $g \lg B$, specifically affects the sporulation-associated phase of glycogen accumulation in Streptomyces aureofaciens. Microbiology 142, 1201-1208.

Hopwood, D. A., Bibb, M. J., Chater, K. F., Kieser, T., Bruton, C. J., Kieser, H. M., Lydiate, D. L. Smith, C. P., Ward, J. M. \& Schrempf, H. (1985). Genetic Manipulation of Streptomyces. A Laboratory Manual. Norwich: The John Innes Foundation.

Horinouchi, S. \& Beppu, T. (1985). Construction and application of a promoter-probe plasmid that allows chromogenic identification in Streptomyces lividans. J Bacteriol 162, 406-412.

Horinouchi, S., Hara, O. \& Beppu, T. (1983). Cloning of a pleiotropic gene that positively controls biosynthesis of A-factor, actinorhodin, and prodigiosin in Streptomyces coelicolor A3(2) and Streptomyces lividans. J Bacteriol 155, 1238-1248.

Ingram, C., Brawner, M., Youngman, P. \& Westpheling, J. (1989). $X y l E$ function as an efficient reporter gene in Streptomyces spp.: use for the study of galP1, a catabolite-controlled promoter. $J$ Bacteriol 171, 6617-6624.

Kormanec, J. \& Farkasovský, M. (1993). Differential expression of principal sigma factor homologues of Streptomyces aureofaciens correlates with the developmental stage. Nucleic Acids Res 21, 3647-3652.

Kormanec, J. \& Farkałovský, M. (1994). Isolation of total RNA 
from yeast and bacteria and detection of rRNA in Northern blots. BioTechniques 17, 838-842.

Kormanec, J., Řežuchová, B. \& Farkašovský, M. (1993). Optimization of Streptomyces aureofaciens transformation and disruption of the $h r d A$ gene encoding a homologue of the principal $\sigma$-factor. J Gen Microbiol 139, 2525-2529.

Kormanec, J., Potúzková, L. \& Řežuchová, B. (1994). The Streptomyces aureofaciens homologue of whiG encoding a putative sigma factor essential for sporulation. Gene 143, 101-103.

Kormanec, J., Lempelová, A., Farkałovský, M. \& Homerová, D. (1995). Cloning, sequencing and expression in Escherichia coli of a Streptomyces aureofaciens gene encoding glyceraldehyde-3phosphate dehydrogenase. Gene 165, 77-80.

Kormanec, J., Homerová, D., Potúžková, L., Nováková, R. \& Řežuchová, B. (1996). Differential expression of two sporulation specific $\sigma$-factors of Streptomyces aureofaciens correlates with the developmental stage. Gene 181, 19-27.

Machida, M., Chang, Y.-C., Manabe, M., Yasakawa, M., Kunihiro, S. \& Jigami, Y. (1996). Molecular cloning of a cDNA encoding enolase from the filamentous fungus, Aspergillus oryzae. Curr Genet 30, 423-431.
Maxam, A. M. \& Gilbert, W. (1980). Sequencing end-labelled DNA with base specific chemical cleavages. Methods Enzymol 65, 499-560.

Pernodet, J. L., Boccard, F., Alegre, M. T., Gagnat, J. \& Guerineau, M. (1989). Organization and nucleotide sequence analysis of a ribosomal RNA gene cluster from Streptomyces ambofaciens. Gene 79, 33-46.

Plaskitt, K. A. \& Chater, K. F. (1995). Influences of developmental genes on localized glycogen deposition in colonies of a mycelial procaryote, Streptomyces coelicolor A3(2): a possible interface between metabolism and morphogenesis. Phil Trans $R$ Soc Lond B 347, 105-121.

Smith, C. P. \& Chater, K. F. (1988). Structure and regulation of controlling sequences for the Streptomyces coelicolor glycerol operon. J Mol Biol 204, 569-580.

Strohl, W. R. (1992). Compilation and analysis of DNA sequences associated with apparent streptomycete promoters. Nucleic Acids Res 20, 961-974.

Received 6 May 1997; revised 18 July 1997; accepted 13 August 1997. 